\title{
Patients with Cancer: Social Representations in Nursing
}

\author{
Abílio Oliveira \\ Instituto Universitário de Lisboa (ISCTE-IUL), and Information Sciences, \\ Technologies and Archictecture Research Centre (ISTAR-IUL), Lisboa, Portugal \\ Email: abilio.oliveira@iscte.pt \\ Filomena Correia \\ Graduated Nurse, specialized in Mental Health, and Psychiatry at Centro Hospital \\ Cova da Beira - Palliative Medicine Service, Covilhã, Portugal \\ Email: filo.amar@gmail.com \\ Maria do Céu Sá \\ Escola Superior de Enfermagem de Lisboa (ESEL), and PhD Student at \\ Universidade Católica Portuguesa (UCP), Lisboa, Portugal. \\ Email: ceu.sa@esel.pt
}

\section{Doi:10.5901/mjss.2015.v6n6s4p495}

\section{Abstract}

\begin{abstract}
The meaning attributed to cancer, when passing the patient-family boundary is, in some degree, also shared between health professionals, which can have effect on the professionals' performance and influence the opinions of users about health services. The focus of this work is the analysis of social representations about patients with cancer, in a population of nurse students, professional nurses working with cancer patients, and professional nurses not working with cancer patients, of both sexes. Our main goal is to know their conceptions towards oncologic patients. The methodological option was the social representations theory. The data was retrieved by questionnaire using the free word association technique. Several Factorial Correspondence Analysis where made to identify the different dimensions (or dependent variables). In general, all professional groups represent oncologic patients by their physical alterations. Nurse students decipher cancer in a distant perspective, as the unknown and something that causes discomfort and eventually... death. In fact, patients with cancer are strongly associated to situations of pain, involving suffering, and death. Women show a more positive perception of cancer, supported in treatment and hoping for a healing possibility. Men demonstrate a greater difficulty in dissociating the patients with cancer of people who soon will die. There is still a long way to walk before cancer patients are no longer associated to a death sign.
\end{abstract}

Keywords: Social representations, nursing, oncologic patient, cancer, pain, death, hope.

\section{Introduction}

Cancer... A simple word... A devastating disease... A terrible reality. More than a severe disease that develops due to undesirable and unpredictable changes at the cellular level, with organic and physiological effects on the body, cancer has a profound impact and harmful repercussions on all dimensions of the person, affecting their personal identity, with psychosocial, emotional, family, social and even economic implications. So, cancer is a 'word' well-known, and feared, being anchored and objectified in many different ways, both at personal as social level.

Known since ancient times, cancer, like other diseases, have contributed to change our language, our attitudes, the way we look at health and disease, and even how we represent ourselves.

Because cancer threat us in an almost uncontrollable way (so as it was considered until very recently), it is a disease that raises great uncertainty and invokes an almost irrational fear, shaking and questioning our lives.

In fact, in most cultures, in contemporary societies, the cancer disease is one of the most feared realities by almost all of us. Of all the ills that we may suffer, cancer has become a major source of anxiety, anguish, uncertainty and fear. This fear is related to the associations established between the word cancer and the experiences of pain, suffering, strain, death and dying (e.g., Cohen et al. 1982; Die Trill, 2002; Duarte, 2000; Ferreira, 1996; Peteet et al., 1992; Sontag, 1998). This negative perception of the disease have impacts on the process of adjustment to it, and also in the process of 
adherence to therapeutic and preventive measures (by patients), the stigmatization of patients, and in the sentiment of hope and will to live of patients with cancer (e.g., Allen et al., 1984; Branco and Pereira, 2006).

Considering the professional performance, the negative representation of the disease has a strong impact on the application of health promotion and in early diagnosis, as well as in the implementation of cancer screening. Its effect is also felt in the quality of life of individuals, directly or indirectly affected by the disease, aggravated by the process of evolution, prognosis and interpersonal relationships between patients and caregivers (e.g. Branco e Pereira, 2006; Martins e Silva, 2002). This interpretation is associated in large part, to the lack of effective treatment for many patients with inoperable metastatic tumours and, someway, is also due to the lack of contact of health professionals with cured patients (e.g., Whelan, 1984).

A better understanding of the representations of nurses about patients with cancer can influence the behaviour of these professionals in order to reduce the mortality and morbidity of patients and intervening more in the recovery and prevention of disease (e.g. Brooks, 1979; Whelan, 1984).

Given the importance of knowledge that health professionals, especially nurses, should have about the oncologic disease, the symbolisms, emotions and images associated with the disease, and on what it represents for patients with cancer, our research is framed on the theory of representations social, as proposed by Moscovici (1961/1976). Social representations (SR) encompass the representations constructed and shared by social groups, modelling the behaviours of their members and giving them a real sense. SR allow us to observe and analyze the way in which the practical knowledge is socially elaborated and shared, contributing to the construction of a common realities to certain social groups, with their specific characteristics (e.g. Oliveira, 2008).

The researches which address social representations in oncology have been focused on the patients and their families (e.g., Ferreira et al., 2005; Martins and Silva, 2002; Santos, 2006; Spink and Gimenez, 1997). In addition, studies about the social representations of nurses, and nurse students, are still scarce in Portugal. So, there should be a real investment in this scientific and professional domain (e.g. Branco and Pereira, 2006).

That also justifies the relevance of our research. The results of this study can have a positive impact on the attitudes of nurses, quality of care and the adoption of strategies that contribute to the reduction of mortality and morbidity associated to patients with cancer diseases.

Thus, our main research purpose relies on the question:

In what extent the representations of patients with cancer may differ among nursing professionals and nursing students (considering their social belongings, such as gender/sex, age and professional experience).

\section{Objectives}

We defined two objectives:

- Identify the representations that structure the thoughts, emotions and feelings in relation to patients with cancer, in a population of students of $1^{\text {st }}$. year of nursing, and nursing professionals - nurses working in an oncology service, and nurses who do not work in an oncology service.

- Verify the differences and similarities of the representations of students and nurses, about patients with cancer, according to their sex/gender, age and professional experience.

\section{Method}

Our empirical research encompasses a broad exploratory study. Here we present part of this study, referring to the participants, variables, mode of collection, processing and interpretation of data.

\subsection{Participants}

The sample consisted of 182 participants. We considered three forms of social categorization: sex/gender (male or female); age (group 1: 18-30 years; group 2: 31-44 years; group 3: 45 or over 45 years) and work experience (nursing students in the first year; nurses who care for cancer patients, designated as oncology nurses, and nurses who do not provide care to cancer patients, designed as non-oncology nurses). Data was collected in the city of Coimbra in the: High School of Nursing, Portuguese Institute of Oncology of Coimbra (devoted to the treatment of patients with cancer), and in Hospital of Covões.

Table 1 presents the distribution of participants by criteria of social categorization. 
Table1 - Distribution of participants by sex/genre, age and professional experience

\begin{tabular}{l|c|c|c|c|c|c}
\hline Age & \multicolumn{2}{|c|}{$\leq 30$} & \multicolumn{2}{c|}{31 to 44} & \multicolumn{2}{c}{$\geq 45$} \\
\hline Sex/Genre & \multicolumn{1}{|c|}{$\mid$} & & & & \\
\hline Students & 45 & 25 & - & - & - & - \\
\hline Non-oncology nurses & 10 & 7 & 19 & 12 & 6 & 1 \\
\hline Oncology nurses & 15 & 4 & 22 & 8 & 6 & 2 \\
\hline Total & 70 & 36 & 41 & 20 & 12 & 3 \\
\hline
\end{tabular}

\subsection{Variables}

The considered independent variables were gender, age and work experience. The dependent variables corresponded to the central dimensions enhanced by participants in relation to patients with cancer.

\subsection{Data collection - Questionnaire}

For data collection, a questionnaire was designed, anonymous and confidential, with open questions in order to identify the semantic universes that structure the thoughts, emotions and images through free word association to the stimuli; "Oncology patients make me think on... "; "Oncology patients make me feel... ".

The free association of words is often used in social sciences, especially when working with the theoretical support I methodological of social representations, as it facilitates access to peripherals and latent content in a certain topic or area. (e.g., Nóbrega, 2001; Oliveira, 2008; Oliveira and Amaral, 2007). This technique allows access to content that make up the social representations. Can thus be overcome some difficulties of methodological and theoretical nature, facilitating the seizure of semantic fields, and from structural and significant properties that are associated with them (Oliveira, 2008).

\subsection{Procedure}

Data collection was preceded by a personal contact with the heads of each service, in order to help us to categorize the service in oncology or non-oncology, taking into account the most frequent pathologies, objectives, and need for care, in each unit of health.

Each participant expressed, individually and anonymously, ideas, thoughts, images, emotions or feelings about the patients with cancer, through words or short sentences, in a maximum of ten, for each of the two stimuli. The purpose of the study was only detailed after the participants completed the questionnaire, so as not to affect the spontaneity of their responses.

\subsection{Data processing}

After collecting and numbering all questionnaires, we proceeded to the reduction of all the words, or short phrases, associated with each of the stimuli. Most of the words and names were put in the male and in the singular and verbs in the infinitive form. Thus, according to an etymological root, we kept words which may have approximate meanings (e.g., Amâncio and Carapinheiro, 1993; Oliveira, 1999, 2008).

To identify the semantic universes (or dimensions) associated with each stimulus were held several Factorial Analysis of Correspondence (FAC). The result of each stimulus (dependent variables) was crossed with the independent variables (sex/gender, age and professional experience), by a statistical package for factorial analysis (SPAD).

\section{Findings}

Overall, we observed that participants have a greater ease to express themselves in terms of thoughts or symbolisms than through emotions or feelings, which corroborates the results of previous work (e.g., Oliveira, 1999, 2008). Next, we synthesize the results for each stimulus, based on the answers of the participants.

For simplicity ${ }^{1}$, we suppress the tables of coordinates and absolute contributions necessary for the interpretation of

\footnotetext{
${ }_{1}^{1}$ And for a question of space (due to understandable publication rules).
} 
the factors resulting from each FAC, where the words retained (as dependent variables that will form aggregates or clusters, as dimensions) are crossed with the independent variables - sex/gender, age and professional experience (cf. Correia, 2008).

\subsection{Thoughts about oncology patients}

From the answers to the stimulus 'Oncology patients make me think on...', we retained 483 words, 17 of which are different (cf. Table 2).

The oncology patient is generally represented as foreshadow of a painful death, a death that frequently occurs in hospital, in a suffering condition, although care and treatment may help to reduce the patient's hard condition, restituting some hope to the patient and family (cf. Table 2).

Table 2 - Retained words by order of frequency

\begin{tabular}{l|c}
\multicolumn{2}{l}{ Oncology patients make me think on... } \\
\hline Word & Frequency \\
\hline suffering & 83 \\
\hline death & 68 \\
\hline pain & 60 \\
\hline hospital & 30 \\
\hline chemotherapy & 28 \\
\hline alopecia & 23 \\
\hline sadness & 22 \\
\hline family & 20 \\
\hline treatment & 20 \\
\hline hope & 19 \\
\hline disease & 19 \\
\hline dependency & 17 \\
\hline image change & 16 \\
\hline cancer & 16 \\
\hline fear & 15 \\
\hline despair & 14 \\
\hline anguish & 13 \\
\hline
\end{tabular}

From the Factorial Analysis of Correspondence (FAC) processed with the selected words, it was considered the first three factors (cf. Table 3).

Taking into consideration the higher values of (absolute and relative) contributions of the words (or dependent variables) in each factor, we can say that the participants, when challenged to think on oncology patients, show ideas and thoughts somehow ambivalent but complementary:

1) On one hand, they demonstrate hope in the treatment and in a possibly cure, and, secondly, patients with cancer are associated to a state of sadness, dependency and changes in their image - or physical aspect;

2) In fact, the oncologic disease, and the oncology patients, are strongly associated to death, dependency and consequent alterations in the image/body (of the patients), despite the hope to face the illness condition, in the present and the future;

3) The illness condition of the patients is intrinsically linked to the state of sadness or malaise of someone who goes to the hospital, sees his body changing/degrading along the time, but still maintain the hope to have a good treatment and, if possible, to be cured. 
Table 3 - Coordinates, Absolute Contributions and Relative Contributions

Oncology patients make me think on...

\begin{tabular}{|c|c|c|c|c|c|c|c|c|c|}
\hline & \multicolumn{3}{|c|}{ Coordinates } & \multicolumn{3}{|c|}{ Absolute Contributions } & \multicolumn{3}{|c|}{ Relative Contributions } \\
\hline & F1 & $\mathrm{F} 2$ & F3 & $\mathrm{F} 1$ & $\mathrm{~F} 2$ & F3 & F1 & $\mathrm{F} 2$ & F3 \\
\hline alopecia & $-0,10$ & 0,01 & $-0,09$ & 0,1 & 0,0 & 0,1 & 0,00 & 0,00 & 0,00 \\
\hline image change & 1,17 & 1,84 & $-0,94$ & 8,5 & 24,4 & 6,8 & 0,12 & 0,3 & 0,08 \\
\hline anguish & 0,63 & $-0,09$ & 0,07 & 2,0 & 0,0 & 0,0 & 0,05 & 0,00 & 0,00 \\
\hline cancer & $-0,51$ & $-0,61$ & $-0,96$ & 1,6 & 2,7 & 7,2 & 0,03 & 0,04 & 0,09 \\
\hline dependency & 1,20 & 2,13 & $-0,04$ & 9,5 & 34,5 & 0,0 & 0,14 & 0,43 & 0,00 \\
\hline despair & 0,44 & $-0,84$ & 0,21 & 1,0 & 4,4 & 0,3 & 0,02 & 0,09 & 0,01 \\
\hline disease & $-0,64$ & $-0,87$ & $-0,20$ & 3,0 & 6,4 & 0,4 & 0,05 & 0,09 & 0,00 \\
\hline pain & 0,23 & $-0,24$ & 0,06 & 1,3 & 1,6 & 0,1 & 0,03 & 0,04 & 0,00 \\
\hline hope & $-2,35$ & 1,28 & 1,66 & 41,1 & 14,0 & 25,2 & 0,49 & 0,15 & 0,25 \\
\hline family & 0,14 & $-0,25$ & $-0,29$ & 0,2 & 0,5 & 0,8 & 0,00 & 0,01 & 0,01 \\
\hline hospital & $-0,44$ & 0,29 & $-0,63$ & 2,3 & 1,2 & 5,8 & 0,04 & 0,02 & 0,09 \\
\hline fear & $-0,98$ & $-0,04$ & 0,28 & 5,6 & 0,0 & 0,6 & 0,09 & 0,00 & 0,01 \\
\hline death & 0,2 & $-0,5$ & $-0,04$ & 1,1 & 7,6 & 0,0 & 0,03 & 0,17 & 0,00 \\
\hline chemotherapy & $-0,3$ & $-0,01$ & $-0,49$ & 1,0 & 0,0 & 3,2 & 0,02 & 0,00 & 0,05 \\
\hline suffering & 0,01 & $-0,08$ & $-0,07$ & 0,0 & 0,2 & 0,2 & 0,00 & 0,00 & 0,00 \\
\hline treatment & $-0,67$ & 0,40 & $-0,31$ & 3,5 & 1,4 & 0,9 & 0,07 & 0,02 & 0,01 \\
\hline sadness & 1,45 & $-0,33$ & 2,14 & 18,1 & 1,1 & 48,4 & 0,24 & 0,01 & 0,51 \\
\hline$\%$ of variance & 10,67 & 9,28 & 8,64 & & $\% \mathrm{Cl}$ & ative & ance & 8,59 & \\
\hline
\end{tabular}

\subsection{Sex/Genre}

Women reveal more positive representations regarding the oncology patients than men, focusing, especially, on patient care - using words such as hospital, chemotherapy and treatment. Men represent the oncology patients, and disease itself, in a more negative way, and even in a fatalistic form, anchored to death, pain and despair.

\subsection{Age}

Individuals over 31 years appear to be more aware of the effects of oncologic disease (than the others), especially of the consequences on a physical level (appointing that disease causes visible changes/damages in their image or physical aspect) and at a cognitive and psychosocial level, with thoughts of pain and suffering. The youngest subjects (18-30 year old) reveal a more general and diffuse interpretation - translated through words as cancer, sadness and despair - seeing the oncologic disease as a sad condition but in which we cannot lose hope. In general, participants over the age of 45 are those who demonstrate greater confidence in the cure of patients.

\subsection{Professional experience (nurses vs nursing students)}

Nursing students reveal a more general perception of the concept of oncologic patient than nursing professionals, linking it directly to cancer, and to the uncertainty and sorrow situation that is associated - using words like cancer, sadness and fear.

Nurses represent in a more objective manner the physical effects of this disease in the human body. However, oncology nurses, more accustomed to caring for patients with cancer, are those who particularly express a more positive attitude toward oncologic patients, to the ways of treatment and to the possibility of cure.

\subsection{Emotions/Sentiments about oncology patients}

After analyzing the answers to the stimulus 'Oncology patients make me feel...', we maintained 366 words, 13 of which are different (cf. Table 4). 
Table 4 - Retained words by order of frequency

\begin{tabular}{l|c}
\multicolumn{2}{c}{ Oncology patients make me feel... } \\
\hline Word & Frequency \\
\hline sadness & 83 \\
\hline anguish & 38 \\
\hline fear & 36 \\
\hline will to help & 32 \\
\hline pain & 31 \\
\hline impotence & 30 \\
\hline sorrow/pity & 28 \\
\hline suffering & 24 \\
\hline hope & 18 \\
\hline revolt & 17 \\
\hline anxiety & 15 \\
\hline disability & 14 \\
\hline
\end{tabular}

For the majority of participants, the oncology patient is perceived as in a general state of malaise, and this image arouses negative feelings or emotions, such as anguish, fear, pain, impotence, sorrow and suffering - in face of such an undesirable and severe condition.

From the Factorial Analysis of Correspondence (FAC) processed with these words (cf. Table 4), we selected three factors (cf. Table 5).

Table 5 - Coordinates, Absolute Contributions and Relative Contributions

Oncology patients make me feel...

\begin{tabular}{l|c|c|c|c|c|c|c|c|c}
\hline & \multicolumn{3}{|c|}{ Coordinates } & \multicolumn{3}{|c|}{ Absolute Contributions } & \multicolumn{3}{c}{ Relative Contributions } \\
\cline { 2 - 11 } & F1 & F2 & F3 & F1 & F2 & F3 & F1 & F2 & F3 \\
\hline anguish & $-0,17$ & $-0,07$ & 0,37 & 0,6 & 0,1 & 3,1 & 0,01 & 0,00 & 0,06 \\
\hline anxiety & 0,11 & $-0,4$ & 1,92 & 0,1 & 1,4 & 32,6 & 0,00 & 0,02 & 0,37 \\
\hline pain & 0,48 & $-0,72$ & 0,5 & 3,7 & 9,2 & 4,6 & 0,07 & 0,16 & 0,08 \\
\hline hope & 1,61 & $-0,79$ & $-0,66$ & 24,2 & 6,3 & 4,7 & 0,32 & 0,08 & 0,05 \\
\hline impotence & $-1,01$ & 1,00 & $-0,26$ & 15,9 & 17,1 & 1,2 & 0,24 & 0,24 & 0,02 \\
\hline disability & $-1,70$ & $-2,36$ & $-1,56$ & 20,9 & 44,0 & 20,1 & 0,24 & 0,46 & 0,20 \\
\hline fear & $-0,16$ & 0,56 & 0,25 & 0,5 & 6,3 & 1,3 & 0,01 & 0,10 & 0,02 \\
\hline sorrow & 0,11 & 0,18 & 0,14 & 0,2 & 0,5 & 0,3 & 0,00 & 0,01 & 0,01 \\
\hline revolt & $-0,38$ & 0,43 & $-0,74$ & 1,2 & 1,7 & 5,5 & 0,02 & 0,02 & 0,07 \\
\hline suffering & 0,42 & $-0,66$ & 0,61 & 2,2 & 5,8 & 5,2 & 0,04 & 0,11 & 0,09 \\
\hline sadness & $-0,32$ & 0,15 & 0,03 & 4,3 & 1,0 & 0,0 & 0,09 & 0,02 & 0,00 \\
\hline will to help & 1,26 & 0,60 & $-1,06$ & 26,3 & 6,5 & 21,4 & 0,35 & 0,08 & 0,25 \\
\hline \% of variance & 13,36 & 12,17 & 11,66 & \multicolumn{7}{c|}{$\%$ cumulative variance $=37,19$} & \\
\hline
\end{tabular}

Participants demonstrate a duality of feelings when they think on oncologic patients:

1) On one hand, they feel will to help, and hope, on the other, they feel impotent to do more for the patient than they already do, in face of the disability and difficulties of the patient;

2) The will to help and their hope in a cure seem to motivate even more the participants to provide care, although the condition in which they find the patients, in a relative state of fear, pain or suffering - sometimes facing their disability or impotence to achieve a better state of health;

3) The anxiety and suffering of the patients, also contributes to arouse a feeling of revolt, and to stimulate, in the health professionals and students, a greater will to help, the best they can, providing the adequate care, with hope.

\subsection{Sex/Genre}

More than men, women reveal emotional closeness, and more easily show involvement and willingness to help patients using words like will to help, anguish and revolt; men also feel sorrow for the condition of the oncologic patient, but they 
hope that the patient can Improve health or be cured.

\subsection{Age}

Younger subjects are those who more easily feel empathy for the persons they see sick and in suffering; they emphasize feelings of sadness regarding the oncologic patients, and a good will to help them. The individuals with more than 30 years, although also reveal empathy and emotional proximity with the patients, they feel revolt and impotent, considering the disabilities and difficulties of the patients. The nurses and nursing students between 31 and 44 years, denote some difficulty to deal with the condition of health/illness of the patients. The subjects with more than 44 years are those who more easily admit they could be in the place of the patients - sharing sentiments of pain, suffering or anxiety.

\subsection{Professional experience}

It appears there is proximity between the sentiments expressed by students and non-oncology nurses - enhanced in words like disability and sadness. The oncology nurses reveal an impressive duality of feelings, particularly expressed in words as anxiety, hope and revolt.

\section{Brief Discussion and Conclusion}

The oncologic diseases remain as serious public health problems, and it will be difficult to find a secure cure in the coming years (e.g. Chang et al, 2006; Santos, 2006). Cancer, and the representations of cancer, implies psychosocial changes which affect not only the individual and his family, as well as society, influencing the language, attitudes about death and life, and the images built on uncertainty, and around the fear, that this disease awakens.

The diffuse social representations about the patients with cancer, relate to the associations established between the word - cancer - and the experiences of pain, suffering, mutilation, dying and death. This grim meaning attributed to the oncologic disease has a strong impact not only on the patient (and his family) but also on health professionals themselves. All of them have common doubts, difficulties and fears, and sometimes they walk by a similar and parallel path, in a society who lives with public and tragic deaths, but tries to deny the 'death of the other', and the right of 'the other' to mourn the death of someone close (e.g. Oliveira, 1999, 2008, 2011).

Several studies show that attitudes of professionals toward cancer patients are related to a negative representation of the disease in itself (as a harbinger of death), and have repercussions both on the quality of professional performance as on the opinion of users of health services (e.g. Branco and Pereira, 2006; Brooks, 1979; Allen et al, 1984). In some way the attitudes of health professionals may interfere with the hope and the will to live of the cancer patients (Allen et al., 1984).

There are few scientific studies that consider the social representations of nurses about oncologic patients in Portugal. The emphasis of research in this area has mainly been directed to the patient and family. The study presented here helps us to understand better the representations that nurses and nursing students have about the oncologic patients.

One of the aspects that we highlight on this research is the strong association of oncologic patient to image changes (or alterations in the body, or physical aspect) and, particularly, to death, despite the advances in diagnosis and therapeutic increasingly deny this relationship - in fact, nowadays, in most cases, oncologic disease can be cured or, at least, patients may have a stable life, since they comply with certain precautions.

We observed, mainly, negative feelings toward the oncologic patient (considering his situation), associated with sadness, suffering and pain, while at the same time there is also hope, in the present and in the future, especially among nurses. Nursing students reveal a more distant perspective (in emotional terms); in their representations the patient with cancer still seems to be something unfamiliar, customizing a condition that causes discomfort, and that leads them to think of death and dying - which may be due, in large part, to the weak (or null) professional experience of these students in dealing with oncologic patients and, in addition, to their learning in the classroom and seminars (where some topics, like death, are still avoided or slightly discussed).

There is still a long way to go, in order to change the harbinger of death associated with the patient with cancer. The big change the perception of the disease is only possible when caregivers, in particular the nurses, change their negative representations on the disease, i.e., when the perspective on the oncologic patients is more constructive, in order to consider them like persons living in a serious disease condition, but with a good chance of recovery or healing, thanks to the care and psychological support that can be provided, and through increasingly sophisticated means and 
treatments.

To concretize this objective can contribute a better understanding in the area of oncology, as well as the implementation and evaluation of training programs, aimed at health professionals - and this training should be launched early, in nursing schools, continuing along the career path. The last reflection of these activities will be increased adherence to preventive measures, early treatment of the disease, a better quality of life for the patient and family and consequently, a decrease in mortality and morbidity from cancer. Then we may feel more comfortable to handle with disease situations - and in particular with oncologic patients -, but also, and this is not least important, with issues of death and life.

\section{References}

Allen, H. et al. (1984). Attitudes towards cancer: Development of the cancer attitudes questionnaire. Cancer, 54, 1124-1129.

Amâncio, L.\& Carapinheiro, G. (1993). Dimensões do poder e do saber. Uma Abordagem Exploratória . In M. Gonçalves (Ed). Comunidade Científica e poder. Lisboa: Edições 70.

Branco, I. \& Pereira, M. (2006). Representação do cancro: Testemunhos de alunos de um curso de licenciatura em enfermagem. Revista de Ciências da Saúde de Macau, 6, 1, 13-17.

Brooks, A. (1979). Public and professional attitudes toward cancer: a view from Great Britain. Cancer Nursing, December, 453-460.

Chang, S. et al. (2006). Epidemiologia do cancer. In R. E. Pollock, et al. (Eds.), Manual de oncologia clínica da UICC (pp. 91-120). São Paulo: Fundação Oncocentro de São Paulo \& Wiley.

Cohen, E. et al. (1982). Attitudes towards cancer: A comparative analyses of cancer patients, medical Students, medical residents, physicians and cancer Educators. Cancer, 50, 1218- 1223.

Correia, F. (2008). Ecos em Fim de Vida: Representações Sociais do Doente Oncológico em Enfermagem. Tese de Mestrado em Oncologia, Porto: Instituto Superior de Ciências Biomédicas Abel Salazar.

Die Trill, M. (2002). Cultura Y cáncer. In M.R. Dias \& E. Durá. (Eds.), Territórios da psicologia oncológica (pp. 639-651). Lisboa: Climepsi Editores.

Duarte, M.D. (2000). A representação do câncer nos enfermeiros. Revista Enfermagem, 2, 19, 36-44.

Ferreira, N. (1996). O câncer e o doente oncológico segundo a visão de enfermeiros. Revista brasileira de cancerologia, 42, 3, 161-170.

Ferreira, N. et al. (2005). Trying to understand the cancer patient experience. Revista Ciências Medicas, 14, 3, 239- 248.

Martins, A. \& Silva, Y. (2002). Doenças oncológicas e representações sociais. Revista Referência, Novembro, 9, 9-24.

Moscovici, S. (1961/1976). La Psychanalyse, son image et son public. 1ª/2a Ed. Paris: PUF.

Moscovici, S. (1988). Notes towards a description of social representations. European Journal of Social Psychology, 18, 211-250.

Nóbrega, S. (2001). Sobre a teoria das representações sociais. In A.S.P Moreira (Ed.), Representações sociais: Teoria e prática (pp. 5587). João Pessoa: Editora Universitária.

Oliveira, A. (1999). O Desafio da Morte: Convite a uma viagem interior. Lisboa: Editorial Notícias.

Oliveira, A. (2008a). Ilusões na idade das emoções: Representações sociais da morte, do suicídio e da música na adolescência. Lisboa: FCT/Fundação Calouste Gulbenkian.

Oliveira, A. (2008b). O Desafio da Morte. Lisboa: Âncora Editora.

Oliveira, A. (2011). O Desafio da Vida. Lisboa: coisas de ler.

Oliveira, A. \& Amâncio, L. (2005). A análise factorial de correspondência no estudo das representações sociais da morte e do suicídio na adolescência. In A. Moreira et al. (Eds.), Perspectivas teórico-metodológicas em representações sociais (pp. 323-362). Paraíba: Ed. Universitária UTPB,

Oliveira, A. \& Amaral, V. (2007). A análise factorial de correspondências na investigação em psicologia: Uma aplicação ao estudo das representações sociais do suicídio adolescente. Análise Psicológica, Série 2 (XXV), 43-65.

Pereira, M. \& Lopes, C. (2005). O doente oncológico e a sua familia. $2^{2}$ Ed. Lisboa: Climepsi Editores.

Peteet, J. et al. (1992), Relationships with patients in oncology: Can a clinician be a friend? Psychiatry. 55, 223-229.

Santos, C. (2006). Doença Oncológica: representação, coping e qualidade de vida. Coimbra: Formasau.

Sontag, S. (1998). A Doença como metáfora e a sida e as suas Metáforas. Lisboa: Quetzal Editores.

Spink, M. \& Gimenez, M. (1997). Representações e estratégias de enfrentamento e bem-estar - psicológico após câncer de mama: Polígrafo.

Whelan, J. (1984). Oncology nurses attitudes toward cancer treatment and survival. Cancer Nursing, October, 375-383. 